超スマート社会を支える分散スパースモデリング 一マルチエージェントネットワーク上のビッグデータ解析—

林 直樹, 永原正章 方向統計学に基づき解明される位相限定相関関数の統計的性質 八巻俊輔 機能安全規格 IEC 61508 の課題と改訂動向

佐藤吉信, 川島 興 無線 LAN 国際規格 IEEE802. 11 の標準化 ITS, ロジスティクスにおける位置情報の活用とその応用作業手順とその最新動向—横田孝義 センサの計測過程におけるセキュリティ＼cjkstart藤本大介

その他

ESS ニュース

2019 年 電子情報通信学会 NOLTAソサイエティ大会 開催報告 木村貴幸 研究会に行こう!

超音波研究会 (US)

VLSI 設計技術專門委員会 (VLD)

近藤 淳

非線形問題研究会 (NLP)

安全性研究会 (SSS)

スマートインフォメディアシステム研究会 (SIS)

小平行秀

島田 裕

伊藤 誠

仲地孝之

応用音響研究会 $(E A)$

古家賢一

安全·安心な生活とICT研究会 (ICTSSL)

不破 泰

国際会議報告

IEEE International Symposium on Information Theory

高邊賢史

11 th Asia-Europe Workshop on Concepts in Information Theory 畺田亜紀子

The 34th International Technical Confernce on Circuits/Systems, Computers

and Communications

宮本俊幸

IEEE International Symposium on Circuits and Systems 田村 裕 受賞者の声

第 75 回(平成 30 年度) 論文賞

参加募集

論文募集
Review Papers

Noboru KUNIHIRO

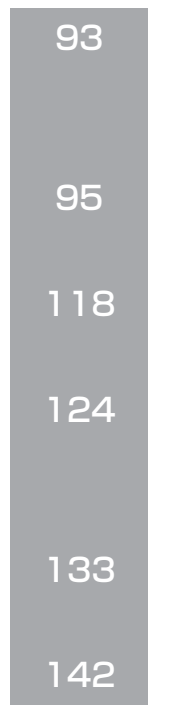

Distributed Sparse Modeling for Society 5.0

Big Data Analysis over Multiagent Networks

Naoki HAYASHI, Masaaki NAGAHARA

Statistical Properties of the Phase-Only Correlation Functions

Clarified through Directional Statistics

Shunsuke YAMAKI

The Current Issues and Trend of Revision of the Functional Safety

Standard IEC 61508

Yoshinobu SATO, Ko KAWASHIMA

IEEE 802.11 WLAN

Standardization Process and Future Trends

Leonardo LANANTE Jr, Yuhei NAGAO, Hiroshi OCHI Utilization of Location Information in ITS and Logistics

A Security on the Sensing Process

Takayoshi YOKOTA

Miscellaneous Articles

Daisuke FUJIMOTO

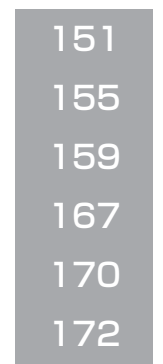

\section{ESS News}

Let's go to IEICE Workshops!

International Conference Report

Winners' Voice

Call for Participants

Call for Papers 